\title{
Landscapes of Thrift and Dwelling: Dwelling and Sociality in Midsomer Murders
}

\author{
By Stefan Zahlmann
}

\begin{abstract}
In its long history of airing the popular crime series Midsomer Murders does not only present various murder cases but also a glimpse into the opinions on gender, sexuality, age and ethnicity. These opinions mirror the attitude of the producers as well as the anticipated expectations of the audience. The dicussion of these aspects are inseperately linked to the categories of thrift and dwelling and it seems that the ways of living in Midsomer County are always overwriting the questions of guilt, atonement and punishment. Furthermore the episodes of the series offer strategies to an aesthetic evaluation of sociality in an fictional countryside. Here murders become not only a question of morality and crime but show the depth of human nature as a hidden reality underneath the scenery of rural purity.
\end{abstract}

Keywords: Midsomer Murders, cottage, mansion, public house, cultural diversity, sexuality.

Zahlmann, Stefan: "Landsacpes of Thrift and Dwelling: Dwelling and Sociality in Midsomer Murders", Culture Unbound, Volume 11, issue 3-4, 2019: 466-484. Published by Linköping University Electronic Press: http://www.cultureunbound. ep.liu.se 


\section{Introduction}

When I was asked to contribute to a thematic section about thrift and dwelling in popular media, I immediately thought of Midsomer Murders. It is obviously a production that is closely tied to the era of "austerity Britain (1939-53)" (Bramall 2013: 1) and its long aftermath stretching to the present. In this series thrift and dwelling are aspects that allow the audience to follow not only a murder case but the struggle of poor versus rich, countryside versus city, old versus young, tradition versus modernity. ${ }^{1}$ Landscape, heritage, ethnicity and gender set the stage for all these battles, intertwined in manifold ways with each other, rendering it far too complex to isolate one of these aspects. Midsomer Murders is located in the fictitious Midsomer County with Causton as county town and more than fifty mostly picturesque villages. In each episode at least one murder occurs, very often many more. The extremely high crime rate would fit better to a large city but adds at least some suspense to the otherwise very decorous lifestyle of the rural population. How to start discussing thrift and dwelling in such a series? Before trying to elucidate what all of these terms could mean in a television series - defining them, outlining their evolution within the series and what may be their relevance for (at least) British society - let us start with the first episode to see what happens when the shadow of murder looms over the sunny realm of Midsomer County, the garden of Good and Evil.

\section{The Beginnings: Midsomer Murders, "The Killings at Badger's Drift”, ITV, March 231997}

Former school teacher Emily Simpson loves photographing rare orchids. On one of her plant forays, she sees something so traumatic that she rushes back to her cottage with her tricycle in a panic. Detective Chief Inspector Tom Barnaby and Detective Sergeant Gavin Troy, having been informed by a suspicious neighbor who is also a keen botanist, later find Emily lifeless at the foot of her stairs, her neck broken, supposedly due to a fall. When it becomes clear that the old lady was murdered, Barnaby discovers that before her death Emily called a helpline and referred to the situation of a women "just like Anabella".

The local undertaker Dennis Rainbird arrives at the scene almost at the same time as the police. Along with his mother Iris he not only profits from prepaid funeral programs but from blackmailing numerous locals. Eventually their spying and blackmailing goes too far and they are both hacked to death by the killer. The undertaker is gay, which is challenging for manly DS Troy, but his death is not seen as a punishment for his homosexual desire, but rather for his and his mother's greed. ${ }^{2}$

Following the trail of the mysterious "Anabella", Barnaby's inquiries lead him 
to Ty House, a mansion that has seen better days, but still has the charm of old splendor. The owner, Henry Trace, lost his first wife Bella in an apparent hunting accident, which was actually murder. Later her sister Phyllis, who was secretly in love with Henry, confessed to killing her and then committed suicide in her cell at the police station. But she had been tricked by the true murderer, and had never done anything wrong except in her fantasies.

It transpires that all the murders were committed by Henry's second wifeto-be, Catharine Lacey, who is incestuously involved with her brother Michael, a local artist. Emily's allusion to "Anabella" refers to a play in which this kind of incestuous love features, as Barnaby realizes at last, when he watches it with his wife in a local theatre.

The first death in the pilot of 1997 was the murder of an old, poor former school teacher, ${ }^{3}$ a "spinster" (00:07:03), ${ }^{4}$ living in the romantically named "Beehive Cottage" (poor, but industrious!) and interested in lovely plants. A grandmotherly economical woman, living alone in a cottage - this spinster stereotype is essential to Midsomer Murders, not due to her appearance in the first minutes of a series which aired more than two decades ago, but because this is iconic characterisation for crime fiction in general, along with its manifold links to the core subject of the series: thrift. The spinster as a figure connects this episode with the Golden Age of crime fiction, which extends back to Agatha Christie's work (Bergin 2012: 85), especially her books on Miss Jane Marple, who is in all aspects like an older sister of Emily Simpson. Merely by this allusion the series is rooted in a history of detective stories that ambiguously combine modern and traditional elements. Unlike the older Sherlock Holmes Stories (by Doyle) or Hercules Poirot cases (by Christie), both of which are very urban and modernist in style, and even though tied to earlier spinster figures in popular culture, the Miss Marple past is a postwar past, the classical era of thrift in Britain. While she travels between unquestioned entities, solving crimes "between city and country, on expertise in both environments" (Deen 2018: 135f), her younger version Simpson is able to act socially simply by living in a setting where landscape and city, heritage and modernity, are understood as mere cultural constructs - and this is a sign of growing "porousness of the rural village" (Deen 2018: 136), which in turn becomes the reason for conflicts about thrift that eventually lead to the crime plots in this series.

The pilot gives the series an exposition that remained virtually unchanged until today's seasons. One central element is the cottage as a home for nice ladies who are the social core of a lovely village. A cottage, surrounded by roses and filled with antique furniture represents an order that is well known from countless movies and TV productions of the fifties and sixties - or of productions that take place in these years. It is the special charm of Midsomer Murders that it offers a visual and narrative experience of this "heritage cinema" (Trimm 2018: 125f, 
McCluskey 2018: 34), not only by the characters depicted but by the villages and landscape - unfortunately with all the conservative features that make it so unfashionable for a modern audience. And this - the struggle to defeat a Britain in decline, to defend this "bastion of Englishness" (a controversial term that will be discussed in the following pages) - is the sign of an underlying plot conflict up to season 15: "Because permanence is felt to be admirable, the English landscape is pervasively antiquated. (...) The landscape is England's prime anachronism - a vast museumised ruin." (Lowenthal 2004: 142)

Here the theme of heritage is most visible: it is the double-edged sword of embracing a past that was perhaps never as bright as its media presentation suggests, and although lovely to behold, has always been considered an element of suppression in a world of social control, crime and judgment. It provides fake history for the audience, but it initiates a series that expects you to embrace not the presence of facts but the mere idea of authenticity to enjoy the plots.

The characters in the series are self-evidently unrealistic. Not because they are played by bad actors, but because there is an obvious disinterest in the actual intimacy of human life. Characters seem to be two-dimensional people taken from a romantic picture. In Midsomer Murders even the main characters from the police force remain distant to the audience (and sometimes to each other), which paradoxically becomes most apparent in the sterile scenes of their private life. Aside from these stereotypes covered in human flesh, there is only one real actor in the series, and that is the stage of the plot: the landscape. And its major role pertains to thrift and other values of public interest (Roe \& Taylor 2014: 8).

The counterpoint to living in a cottage (signifying a life of humble thrift and inner beauty) is living in a mansion. This is not a life of thrift but often of carefully maintained remnants of former luxury. The "grand house" in this and in many other episodes has a real double meaning: it is not only a very big house, surrounded by a vast estate and impressive gardens, it is also inhabited by families of grandeur who can proudly look back on decades if not centuries of political and economic influence. At least until the very particular situation that is shown in the Midsomer Murders episode where this family is introduced. It seems that these families are on the brink of shifting from history to modernity. And due to the conservative undercurrents of this series it is most often a young woman, a newcomer, who turns the splendor into social relegation. In the pilot it is the scheme of the pretty young bride to combine the status of a Lady with the benefits of cheating on her wheelchair-bound old husband for a more attractive young man, who happens to be her brother. In plots like these the younger new wife has been unable to manage her greed for money properly. ${ }^{5}$

The cottage and the mansion are not a pair of opposites of dwelling but are complementary. The inhabitants of both spheres accept the same set of social rules 
and have no plans to change it. It is merely the crime that disturbs this traditional heritage and questions the legitimacy of an old order facing the challenges of modern times. The comforting and reassuring common ground is vanishing, the heritage is dishonored.

The duo of detective sergeant and inspector in the early seasons is the entity that has to deal with the problematic implications of thinking that a "murderer" is never held to be a part of the unchangeable old but is something new. ${ }^{6}$ This novelty cannot be controlled by the set of inherited rules, and because of its criminal character cannot become a topic of discussing the necessity for change. Rather, for the Midsomer community, it becomes nothing less than an indication of a disrupted society. The authority of the policemen is the only force that is able to solve this conflict between old and new - not by enforcing modernity, but by reinstating the traditional rules. "Murder" in the show's early years is somehow the inevitable way of cleansing the Midsomer community of its own destructive elements. It is a sort of purgatory to defend the old, because the new has no legitimate status yet.

The phenomenological start of this essay, which simply describes what an audience sees in the first minutes of the series' pilot, the first impressions and how to approach the implications of Midsomer Murders, needs a theoretical base for discussing the relevance of thrift and dwelling and for defining its cultural dimensions for an audience.

\section{Thrift and dwelling in Midsomer Murders}

The relation of thrift and dwelling in Midsomer Murders becomes highly visible in the media dispute with heritage. This is not only an aesthetic element of the series, but becomes in the crime aspects, i.e. on the level of the stories told, a conflict between the status of a heritage-based cultural identity and human rights, basically represented in the right to not be physically harmed, but, in fact, in the awareness and acceptance of ethnic, sexual, and social difference as well. For the viewers, in the safety of their armchairs, watching the series gives an additional pleasure in contextualizing Midsomer Murders in the history of British crime fiction and countryside drama, enjoying "ecomuseal" (Davis \& Corsane 2014: 118) allusions of various kinds. Midsomer Murders is an example within the genre of crime series that links the concepts of thrift and dwelling in rural culture. The most important feature in this entertaining blend is that it is not real at all, it is a mixture of past and present stereotypes, cultural citations of imagined national and local identities and - among many other fictions - of the countryside as a "value-laden entity" (Roe \& Taylor 2014a: 1).

You do not find anything real concerning thrift and dwelling in Britain in this series, but you will no doubt glimpse a visual discourse on the meaning of thrift 
and dwelling considered to be apt for an international audience. The only reality confronting the viewer in this series is the joy or disgust you feel about the concepts shown - and this will make you part of the following discussion.

\section{Midsomer Murders as a part of British cultural heritage}

Midsomer Murders shares the fate of a great many media products that are negatively criticized by many viewers, secretly enjoyed by many more, but almost academically unrecognized (Bergin 2012: 83). The series is an ITV detective drama running since 1997. The pilot of Midsomer Murders, "The Killings at Badger's Drift", along with the first episodes, was based on the Inspector Barnaby novels of Caroline Graham and adapted by Anthony Horowitz. The start of the regular series in 1998 led to twenty-one seasons to date. Since in countries like Germany it is aired under the title Inspector Barnaby the production needed to create a sort of family connection between Tom Barnaby, the original character played by John Nettles, and John Barnaby, the new inspector embodied by Neil Dudgeon since season 14 .

Although this new face was not the only change the audience had to accept, the new story lines, sets, and casts (with a focus on diversity of all kinds) were not as negatively received by the audience as one would imagine. ${ }^{7}$ The obvious division between the "old" and the "new" seasons relates to a controversy caused by the former producer Brian True-May (Bergin 2012: 95). In 2011 True-May said in an interview that the series was "the last bastion of Englishness" and "that it appeals to a certain audience, which seems to succeed" (https://www.bbc.com/news/uk12741847). In his eyes it seemed unproblematic for the audience that there are no prominently featured non-white characters. True-May eventually stepped down as producer, "to pursue further projects" (Bergin 2012: 92), and made way for a more ethnically diverse picture of British society since season $15 .{ }^{8}$ His intention has been problematic, but the core of his argument remains the same: "Englishness" is the essential theme of this crime series. But within this concept must be included a struggle that shapes the episodes of all seasons. In this essay seasons 1 to 14 are sometimes called the "early" seasons, subsequent seasons the "new" ones, starting with 2012. Obviously True-May's proclaimed true Englishness is nothing more than an "England-Land" (Lowenthal 2004: 147), a media theme park to visit via television. And a way of fighting the doubters as to whether Britain ever existed in the way modern culture remembers it (Wand 2004: 242, Bergin 2012: 92).

Midsomer Murders is sold to a large number of countries and praised in reviews for its countryside aesthetics and rural crime plots. In the societies of Western television culture there seems to be a ready acceptance for mystery located in the concept of a "typically" British countryside. 


\section{Thrift and dwelling as media constructs}

What is meant by categories like "thrift" and "dwelling" in this essay? Normally it is relatively easy to define both terms economically, politically, socially or historically in a way that seems to establish them as facts, positive entities or aspects that are so obvious that it makes them indisputable. A series like Midsomer Murders is pure fiction. It is not a "mirror" of facts, but always an enactment, a picture of a scene. A mirror might physically be objective, but what one sees in a mirror depends on the person looking into it. All major themes discussed in this text have to be considered the result of the work of subjects, numerous people involved in the production - and the creative, producing mind of each viewer watching episodes of this series (Tschiggerl et al. 2019: 81). Categories like thrift and dwelling enable academics to watch the series in certain ways, but are not defined in this media as they are in a scholarly textbook. Even though thrift and dwelling are the focus of this volume, one should consider that both aspects in Midsomer Murders are sometimes visible in a rather oblique or, on the contrary, an over the top way. Not losing focus seems possible by using a single term like "heritage" to gain a combined access to media concepts of thrift and dwelling.

For me thrift is therefore not a mere economic procedure but a media enactment of a cultural practice. It is, especially combined with the concept of dwelling, not only a way of living but an actively chosen or forced way of showing individual connections to a certain community, to concepts of sometimes multiple pasts, presents, and futures. It combines biographical features with social, aesthetic, historical, ecological, artistic, and even more aspects - in the case of Midsomer Murders, you have to add criminal aspects. It is symbolized in objects and practices as manifold as the persons that are involved. One very prominent way to discuss thrift in a crime series is to link it to murder: the need for money, if you are poor; the greed for more money, if you are rich, are the most obvious motives imaginable for a crime. But the plots in Midsomer Murders are generally more sophisticated, especially when thrift and dwelling open a field of tension of various emotions like revenge or desire. As regards the series I clearly differentiate between saving and thrift, and link both to the cultural spheres of the city and the countryside (Färber \& Otto 2016: 27ff). In the societies of Western civilisation we all live in "urbanized" (Fouquet \& Zeilinger 2009: 9) cultures - the concept of urban life is ubiquitous even if one avoids cities and prefers villages - and because of that we need cultural patterns and objects to connect ourselves to the spheres we would like to be associated with. Just to name a few countryside examples: folk music, organic food, jeeps, clothing, hunting - and even watching series like Midsomer Murders can connect us to a concept of living that seems to be easier to control by the individuum than life in an urban structure. Thrift in Midsomer Murders means a connection to the values of a rural or village society. 
By "dwelling" I mean all forms of living in a sheltered home shown in this series: from a bed in a barn to traveling in a caravan ${ }^{9}$ to living in a luxury mansion, willingly or unwillingly. In Midsomer County dwelling also determines the level of involvement in social structures - from the life of a hermit to a public figure. It establishes the ways of being present in public places, too, when it becomes key to spending time in a community.

For a visual media like television dwelling is a fundamental topic. The way of living and the style of a house for example instantly tells the audience a lot of aspects necessary for understanding the plot. In combination with the concept of thrift it establishes a connection between a character and the particular community the person wants or has to live in. Bearing the fictitious nature of Midsomer Murders in mind, it resembles a presence and a past of a "good old England", real or imagined, that is familiar to many. There is no real thrift shown in Midsomer Murders, not even the homeless have to be hungry, ${ }^{10}$ thrift is only an enactment of a modest, mainly analogue ${ }^{11}$ lifestyle. Thrift in Midsomer is only an embodiment of an "austerity chic" (Bramall 2013: 17), because life in the countryside is promulgated as being easy and uncomplicated.

If a series like Midsomer Murders is not an official record of thrift and dwelling in the contemporary British countryside, but subjective reflections on it, the question arises as to the aim of this sort of entertainment. Here the concept of heritage comes into play: here heritage is of course not a depiction of cultural remembrance in Great Britain but a media blend of collective memories of countryside clichés, of transferred values, traditions, and responsibilities - and of the rules of crime storytelling extending from Sir Arthur Conan Doyle and Agatha Christie to the present. When citing these aspects this series offers a sort of reflexive, ironic, easy access to major topics concerning British cultural memory.

\section{New Beginnings: Midsomer Murders, "The Dark Rider", ITV, February 12012}

The impressive Quitewell Hall is the site of the annual Civil war re-enactment of the Midsomer Community. Inspector John Barnaby, the cousin of retired Tom Barnaby, and Ben Jones have to investigate the death of Bentham DeQuetteville, who fell from the roof of his mansion. Shortly before he died he told his son Toby that the headless Dark Rider Geoffrey had appeared on a white stallion, pointed at him and condemned him to die. Over the next few days the Dark Rider reappears twice, leading to the deaths of Julian and Ludo DeQuetteville, and dramatically changing the line of succession for the house and estate.

The Civil War battle re-enactment on Long Meadow is supervised by John Barnaby's wife Sarah, a member of the Midsomer Historical Society, and will, if 
the Roundheads win, alter the possession of the location. Long Meadow would become the property of Harry Fleetwood who would permit all social events. Fleetwood's wife Sasha turns out to be a partner in crime with Toby DeQuettville. She was the Dark Rider, and together they committed the crimes.

This was the first episode after the producer Brian True-May left the production team following his controversial interview, and the first of season 15. It seems that this particular episode not only revises the core values of the early years of Midsomer Murders but even reveals its artificial nature as a series. History and heritage form part of the plot and are a means of criticizing Midsomer Murders as well. The re-enactment of a historic battle, used by the protagonists to create a "usable past" (Smith 2004: 302), which is not at all in accordance with historic facts but rather with today's longings for more wealth by some members of the gentry, is turned into a beer- and violence-loaded turmoil to entertain the local villagers. Heritage becomes simply a fiction, and, if it does not meet the needs of the public, is nothing more than fraud. This attitude is also reflected in the setting of the "Old Houses": Quitewell Hall is a dusty house belonging to a family that is not even doing well. The inhabitants of the mansion are depicted as retarded, criminal and chained to a past that they despise but have to sell to the public to make a living. And the whole business is not even managed by an old aristocrat but is totally dependent on the efforts of the young working-class wife of the eventual heir. Dwelling, thrift, landscape, gender roles and heritage become aspects either to laugh at or to see with a totally new meaning. Although the change from Tom to John Barnaby occurred in episode 82, many features of earlier seasons remained untouched until this episode. Midsomer Murders starts in season 15 with a totally new way of presenting the plot of a crime series.

One of these beginnings has a flaw, however. Sarah Barnaby, who in this episode proclaims to Ben Jones that she is an individual, independent from her husband's ideas, tries to direct the re-enactment but fails horribly. She does not realize that "history" in Midsomer is not related to academic facts, but simply to public fun: the participants want to get totally drunk and end the occasion in a proper brawl, still in their historical costumes. And no one has written into her script that the series is now trying to be self-mocking. It is extremely cynical that her efforts to make history alive and to be part of the commonly shared past of a divided country population - a true heritage for the present - not only is not credited with success, but makes her look like a fool. Unlike Joyce, the wife of the former Inspector Tom Barnaby, Sarah is much more independent of her husband, successful in her job as a school teacher, and much more of a social team player than a mere housewife. The relationship with her husband is laid-back, since John is a very popular and relaxed policeman who (unlike Tom) does not need the help of his wife to get access to various social events. 
"The Dark Rider" links thrift with history: the latter is presented as a common good that can be consumed by everyone whatever their social status. And due to its connection to thrift, it can be understood as straightforward fun - it is even possible for members of the DQ family to blend family history and their style of dwelling into the fabric of an all-English concept of community life.

The life of the local gentry, very often morally criticized in previous seasons when it turns out that a case is related to their misbehavior, now becomes a parody of people with wealth and ancestry: due to inbreeding over generations, the male members of the DeQuettevilles all seem somewhat "strange" in their habits, if not absolutely crazy. The series' long tradition of presenting whimsical old people of status, previously brought to perfection, ${ }^{12}$ in this episode at least gets a counterpoint in the atmosphere at Quitewell Hall. The name seems to allow the Midsomer community and especially the many foreign tourists to gain access to a picturesque concept of nobility. Separated from the (paying) visitors in their house only by red ropes the family fakes an aristocratic British lifestyle: painting, reading old books, drinking tea. And, of course, they despise the social order of Midsomer, represented by Barnaby and Jones. The only rules that count for the DQ family is, as in previous seasons for the nobility, the private order that is based on dwelling in a feudal mansion.

Their neighbor, Harry Fleetwood, represents another family of status. Due to a victory in the Civil War over the troops of the DQ family the Fleetwoods are their hereditary enemies. Harry lives in a high-tech mansion and, as always in Midsomer Murders, contrasting life in an historic mansion or a cottage enriches the concept of dwelling with the theme of modernity. Here the confrontation with heritage is shown as a battle of concepts. Historical heritage is always present but only in a controlled environment: it is shown as little tin soldiers, embodied in attractive sandbox arrangements of the historic battle between both families. This sandbox is the centerpiece of a home office that would suit a New York City investment bank. The modernist aspects of his lifestyle could not contrast more with Lady Isobel's attempts at producing romantic landscape painting for house-touring tourists. The future of the gentry in this episode is about adapting family history to the challenges of social change. Harry is not the most likeable character in this episode - he is far too rich to be a really honest guy in the logic of this series - but in waiving the win of his wife's bet (over the ownership of Long Meadow) with Julian, he at least shows that he has class and decency.

The relationship between Barnaby and his assistant in this case study is totally different from the subordination shown in the pilot or first seasons. Jones only reluctantly accepted Barnaby as a superior, since he had hoped that after Tom's retirement he would become the new Chief Superintendent. His new boss, schooled in psychology (whereas Tom works by intuition) and dependent on his knowledge 
of local affairs becomes an object of his mockery. Not only is this totally exceptional - Barnaby usually plays jokes on his subordinates - it is matched by the fact that Jones has a girlfriend, gets a promotion to the Secret Service, and after his exit as a character reappears in episode 113 with an equal rank. Other assistants in the early seasons are depicted more or less as morons, overwhelmed by situations such as dealing with gays and lesbians, being unable to drive properly and so on. Detective Sergeant Daniel Scott, the second assistant, was a character that the production was unable to handle properly in the storyline. Introduced as a cocky assistant in episode 30, the manly and attractive DS was very flirtatious with some of the female witnesses. In his first episode Scott even charmed a gay character, who was until then very difficult to question, in such a way that his boss makes jokes about it. ${ }^{13}$ The notorious flirting should not be the major feature of this character: he openly interprets his relocation to Midsomer as a sort of disciplinary measure to tamp him down. And he refuses to adjust to the rules and collective knowledge that make Midsomer the community it is. In episode 44 he suddenly becomes ill and his character is instantly replaced by Ben Jones. Subsequent to Jones, the characters are either extremely insipid or portrayed as cute, immaculate, sex-free country boys. Other than Jones and his girlfriend, none of them have a mature private life that is equal to Barnaby's marriage. Only the two Barnabys have real family lives, and even a family past that is relevant to the storyline, and their sexual identity not been challenged by any other policeman. Their subordinates even have problematic housing situations, underlining the central theme of dwelling in the Midsomer plots: if you do not live properly, you are not a proper member of the community. And if you have a family you are a link in a chain that binds you to its history, you are an essential part of a heritage that extends beyond your personal life and connects you with society.

The binary structure of cottage/mansion that is shown in the early years of Midsomer Murders, which in this particular episode extends to a newly built modern style Fleetwood Hall, is always based on dichotomies like "poor and rich" or "old and new". In any case, it is a rural way of living that is being portrayed. The fabric of community life in the new seasons opens up to a more urban lifestyle: Midsomer is no longer the secluded hideaway of rose-loving ladies and fox-hunting gentry, but also home to a working class, that lives in apartment blocks and buys groceries in suburban malls. The city and the countryside can be seen as cultural concepts rather than geographical spaces: Midsomer and its villages evince a mindset that promotes (especially in the later seasons) the spirit of community, ecological life, sexual and ethnic diversity, a model for "cosmic harmony and social justice" (Kohl 2006: 185) - based on, and to be understood as, an enrichment (Bramall 2014: 203) of the described true Englishness. The city, often the mere name "London" figures as the polar opposite of the countryside; although it is 
not visually shown, characters interpret it as a sphere of impersonality, pursuit of profits, and loneliness. Diversity, by contrast, not only enriches the crime plots but broadens the scope of cultural heritage - and the countryside - as well: "New cultural practices, especially to do with the family and religion, have become a feature of British landscape; skin color, identities, relationships of even British-born individuals." (Modood 2004: 85).

Dwelling is not only an aspect that is defined by an individual's attitude to thrift. It is a concept that includes or excludes people according to certain features. Gender, age, and ethnicity; being mentally or physically disabled is also something that enables individuals access to public spheres - or not, as the case may be.${ }^{14} \mathrm{Be}$ ing old, female, and unable to walk is not considered problematic in Midsomer, if you are rich enough to compensate for each and every aspect by financial means. But it can be considered immoral - here thrift becomes the overriding aspect - if it is the result of trying to gain "status". One might even say that "naturally", in the logic of Midsomer Murders, the lady in question is confined to her wheelchair and her husband's mansion. ${ }^{15}$ She finds her counterpart in a later episode where a hard-of-hearing young man is chatting in a pub with a hearing device that broadens his social sphere with ease. ${ }^{16}$ While he seems to be deaf from birth, the lady suffers from the consequences of a riding accident. Again, aristocratic life in the logic of the series is considered less acceptable than thrift. It therefore depicts the negative aspects of heritage: the mental weakness of predominantly male or very old members of the gentry not only explains the motives behind many of the crimes, it also contrasts with the lives, well-being and struggle of the common people of Midsomer. It is a symbol of decadence - one of the fables of the British downfall (Aughey 2004: 47), so vividly and regularly interwoven with media crime stories.

\section{Conclusion: The pubs, fairs and cricket games in the landscapes of thrift and dwelling}

Dwelling in Midsomer is strongly connected to concepts of thrift. Even the addition of suburban apartments for the young and poor only expands, but does not erase, the dichotomy of cottage and mansion or of rural and urban areas, as well as the struggle to make a living in Midsomer or live up to Midsomer's social standards. In the cultural landscapes of an invented Britain - not rural at all, but seemingly natural (Shaw 2018: 73) - there have to be spheres that are open to the public, that enable people to interact with each other despite where they live. The need for plots wherein not every corpse is found at the foot of a private staircase or on a gravel drive behind a Bentley proves the necessity for public places. Sometimes the crimes themselves happen right in the public eye, sometimes future suspects meet or quarrel for all to see. But where? Midsomer Murders offers three 
different concepts of sociability associated with thrift and dwelling. All of them are deeply linked to the phenomenon of heritage and commitment: engaging with heritage, seeing oneself in a line of succession, and living in a tapestry of tradition, requires a way of life that is open to the public. To reiterate, thrift and dwelling are not seen as realities but as media concepts of everyday life.

The first concept is the public house. In the early seasons the pub is the legitimate place of social interaction. A pub offers food, drink and shelter for people who are thought to lead a thrifty life, as well as easing the stressful working schedule of wealthy people. In the episodes directed by True-May the "gentrified pub" (a former pub turned into a concept-based restaurant, e.g. for ethnic or vegan food) could in later seasons become the obvious setting for a crime in an ethnically diverse local community. Unlike the pub, which is mainly associated with the evening and (despite waitresses) with local men (women in the early seasons are confined to the domestic sphere of house and garden), the gentrified pub is open to all genders, ethnic groups and daytime traffic as well, which expands the range of possible crimes and suspects.

Even more open, to social accessibility and different sorts of crimes, are Midsomer's public fairs and shows, the second concept of sociability. The wide range of flower shows, animal fairs, book fairs, music fests, garden contests, even Wild West rodeos, ${ }^{17}$ and more are not only open to Midsomer locals of all kinds but to tourists as well. The new seasons openly emphasize that life in Midsomer must be considered a staged form of living, a museum of Englishness, that needs the perpetual effort of villagers and money from the outside world simply to maintain the facade of thrift and rusticity. In this logic the admiration of outside visitors to these fairs extends the social fabric of the Midsomer community.

Increasingly open to new residents and guests are cricket games, the third concept of sociability. ${ }^{18}$ The games shown in the series are not only sporting events but battlegrounds of social disruption in the early years and social change in the later. Problematic consequences of rural gentrification are portrayed by the example of a new set of rules, the "C- 10 " ${ }^{19}$ which for fans of the game can easily be identified as an alternative way of playing cricket, Twenty20. It is open to all available forms of thrift in Midsomer as well as all concepts of dwelling. Here the gentry challenge the locals and vice versa. Even policemen and old ladies become equal competitors. The game is a recurring element of the series, and serves as an indicator of plot development towards more political correctness. Cricket becomes a reality inside a media reality. And given the saying that if Jesus did any sport it would be cricket, ${ }^{20}$ this adds the concept of divine order to the worldly rules.

Somehow the episodes of the later years, i.e. the time after Brian True-May, seem to respond to all the questions that are raised in the early years. It is not only that the crimes can be interpreted differently, but that they are no longer whodun- 
nit remakes of the golden Agatha Christie age; they open television up to discussions of social conflicts that shape the British present. It is obvious that the connections between thrift and dwelling after season 14 have changed. Although the dichotomy of cottage and mansion remains, it is no longer a symbol of an established conservatism, but is open to new sorts of crimes based on new forms of life and death respectively. There is a different use of concepts of the past compared to the early years. The media past underlines the necessity of living in the present and for the future. Nostalgia is not a stash of childhood memories any more, but rather a new way to understand and embrace the inevitability of change and time passing. One question remains: why do the seasons produced by Brian True-May remain so popular, and - if you read customer reviews at streaming services - are they often considered the "real" Midsomer Murders? A possible answer is that they are so deeply linked to the era of austerity Britain - and to even older middle class ideals of the countryside (Berberich 2004: 375, Berberich 2006: 209) - which is so intertwined with British cultural memory, that it seems almost "natural" to be setting mystery episodes in the countryside of Midsomer County. In other words: they symbolize an almost sacrosanct heritage of true Englishness untouched by audience criticism, which now lives in a globalized, digital world and engages in new cultural discourses. Following this logic, the media representation of this era of a commonly shared past has been actively used as a tool to defend a discourse that would keep diversity of all kinds at bay. It does not concern me if this style of television-making is still appealing to the public, I am simply interested in arguing that the later seasons try to discuss thrift and dwelling differently, by linking it intellectually with heritage, immigration and integration in a way that appeals to a more critical audience, and by means of humor: "New cultural practices (...) have become a feature of British landscape; skin colour, identities, relationships of even British-born individuals" (Modood 2004: 85). For me it is significant who these seasons include and who they exclude - and whether the concepts of identity promoted through heritage in these provide narratives for future social inclusion or exclusion. From this perspective Midsomer Murders is more than a television program, it is one battleground of a society struggling for a modern Britishness.

Stefan Zahlmann, Professor for History and Theory of Media Cultures from the 18th to the 20th century, Department of History, University of Vienna. Research interests: Theory of history, popular culture, ecology, animal studies, antiurbanism, science fiction, fantasy, computer games. E-mail: stefan.zahlmann@univie. ac.at 


\section{Notes}

${ }^{1}$ The British rural setting in popular television was already the basis for my article on the series All Creatures Great and Small (1977-90). It shows similarities in dealing with thrift/dwelling and is historically much more linked with the time of "austerity Britain" See Stefan Zahlmann (2015): Tiere und Medien, in: Gesine Krüger, Aline Steinbrecher, Clemens Wischermann (eds.): Tiere und Geschichte. Konturen einer Geschichte der Animate History, Stuttgart (Steiner), S. 153-170.

${ }^{2} \mathrm{He}$ drives an expensive, customised German car, which makes him suspicious, since it contradicts the Midsomer rules of thrift. In the world of this series being gay or lesbian is not linked to particular forms of thrift, but it does get the same police attention as promiscuity or adultery (see S02, E01 "Death's Shadow"; S02, E02 "Strangler's Wood") if the character is involved in a crime. In S02, E03 "Dead Man's Eleven" a gay character from a previous episode is mentioned as having moved to Morocco, in an apparent reference to Sebastian Flyte's fate in "Brideshead Revisited", who went to Tunisia. In S01, E01 "Written in Blood", when a gay soldier mets his lover in Turkey, homosexuality and exotism are obviously intertwined in the plots. In the early years of the series, gay and lesbian characters involved in crimes seem to leave the communities of Midsomer very soon (see S01, E03 "Faithful unto Death"; S03, E02 "Blue Herrings"), but in the later seasons they remain (see S16, E02 "Let Us Prey"; S18, E02 "The Incident at Cooper Hill"). In the later seasons being openly homosexual is portrayed as a legitimate way of living in a village community.

${ }^{3}$ In the logic of the early seasons open sexual activity is linked to crime, decadence, and luxury (see S01, E01 "Written in Blood"; S01, E04 "Death in Disguise"; S03, E03 "Judgement Day"). What better symbol for thrift than a poor old lady living in a cottage who is fascinated by beautiful flowers? This pilot concept was only trumped by the lives of four nuns, who run an almost derelict abbey and rely totally on the vegetarian bounty of their own gardens in S17, E07 "A Sacred Trust".

${ }^{4}$ Quotations from the episodes are cited as follows: hour/minute/seconds.

${ }^{5}$ See S04, E01 "Garden of Death". Here the young woman in the mansion has matured to a widow, who is very rich and has sex with the gardener. She is killed because she is not honoring the local memorial culture.

${ }^{6}$ See S02, E02 "Strangler's Wood".

${ }^{7}$ On amazon.com only one review can be found with the complaint that in the new seasons “[t]here's almost always perverts involved!"See: https://www.amazon.com/ Midsomer-Murders-Series-16/product-reviews/B018HCA41W/ref=cm_cr_dp_d_ hist_1?ie=UTF8\&filterByStar=one_star\&reviewerType=all_reviews\#reviews-filter-bar

${ }^{8}$ https://www.theguardian.com/media/2011/mar/23/midsomer-murders-brian-true-may-english; https://www.radiotimes.com/news/2011-03-23/midsomer-murders-boss-brian-true-may-to-step-down/. 


\footnotetext{
${ }^{9}$ At least three times people are depicted living in caravans: see S02, E04 "Blood Will Out" ("Romanichals", here called "travellers", who are featured extremely positively due to their thrift); S18, E06 "Harvest of Souls" (the owners of an amusement ride); S19, E04 "Red in Tooth and Claw" (when the victim is forced to live in a caravan).

${ }^{10}$ See S03, E01 "Death of a Stranger".

${ }^{11}$ See S07, E06 "The Straw Woman"; S10, E06 "Picture of Innocence" (analogue photography); S12, E02 "The Black Book" (information is gathered in a public library, not online).

${ }^{12}$ See S14, E02 "Dark Secrets": The bizarre setting of William and Mary Bingham's lifestyle depicts an extremely charismatic, but demented elderly couple living secluded from the world in a mansion filled with memories and waste, which they never want to leave.

${ }^{13}$ See S07, E02 "Bad Tidings".

${ }^{14}$ Visible scars are a heavily distinctive feature in the Midsomer world that either are to be hidden (e.g. with gloves, see S07, E04 "Sins of Commission"), or which force people to hide at home (see S14, E02 "Dark Secrets").

${ }^{15}$ See S08, E06 "Hidden Depth". She even shows a longing for thrift. The very first morning after her husband is killed she has an English breakfast with brown sauce: "Brown sauce. I haven't been allowed brown sauce for thirty years!" (00:48:52). Eating is very often connected to thrift; even Tom Barnaby is deeply rooted in a family history of eating a traditional condiment: see S08, E07 "Sauce for the Goose".

${ }^{16}$ See S19, E02 "Crime and Punishment".

${ }^{17}$ Among from the wide range of such shows in Midsomer Murders see S03, E03 "Judgement Day" (village competition); S08, E03 "Orchis Fatalis" (flower show); S13, E03 "Blood on the Saddle" (rodeo).

${ }^{18}$ See S02, E03 “Dead Man's Eleven“; S12, E03 “Secrets and Spies“; S19, E03 "Last Man Out".

${ }^{19}$ See S19, E03 "Last Man Out".

${ }^{20}$ See S02, E03 "Dead Man’s Eleven“.
}

\section{References}

Aughey, Arthur (2004): “Three Fables of Britishness", Helen Brocklehurst \& Robert Phillips (eds): History, Nationhood and the Question of Britain, Houndmills et al.: Palgrave Macmillan, 45-56.

Berberich, Christine (2004): 'I was Meditating about England': The Importance of Rural England for the Construction of 'Englishness', Helen Brocklehurst \& Robert Phillips (eds): History, Nationhood and the Question of Britain, Houndmills et al.: Palgrave Macmillan, 375-385.

Berberich, Christine (2006): This green and pleasant land: Cultural Construction of Englishness, Robert Burden \& Stephan Kohl (eds): Landscape and Englishness, Amsterdam: Rodopi B.V., 207-244.

Bergin, Tiffany (2012): Identity and nostalgia in a globalized world: Investigating the international popularity of Midsomer Murders, Crime Media Culture 9:1, 83-99. 


\section{Culture Unbound}

Journal of Current Cultural Research

Bluemel, Kristin (2018) \& Michael McCluskey (eds): Rural Modernity in Britain. A Critical Intervention, Edinburgh: Edinburgh University Press.

Bramall, Rebecca (2013): The Cultural Politics of Austerity: Past and Present in Austere Times, Basingstoke et al.: Palgrave Macmillan.

Bramall, Rebecca (2014): Memory, meaning, and multidirectionality: 'Remembering austerity Britain', Lucy Noakes \& Juliette Pattinson (eds): British Cultural Memory and the Second World War, London, New York: Bloomsbury, 195-211.

Brocklehurst, Helen (2004) \& Robert Phillips (eds): History, Nationhood and the Question of Britain, Houndmills et al.: Palgrave Macmillan.

Burden, Robert (2006) \& Stephan Kohl (eds): Landscape and Englishness, Amsterdam: Rodopi B.V.

Davis, Peter (2014) \& Gerard Corsane: Communities, heritage and new cultural landscapes: ecomuseological approaches, Maggie Roe \& Ken Taylor (eds): New Cultural Landscapes, New York: Routledge, 118-135.

Deen, Stella (2018): The Spinster in Eden: Reclaiming Civilisation in Interwar British Rural Fiction, Kristin Bluemel \& Michael McCluskey (eds): Rural Modernity in Britain. A Critical Intervention, Edinburgh: Edinburgh University Press, 135-148.

Färber, Alexa \& Birke Otto (2016): Saving (in) a common world, Anders Blok \& Ignacio Farias (eds): Urban Cosmopolitics, London et al.: Routledge, 25-42.

Fouquet, Gerhard \& Gabriel Zeilinger (2009): Die Städte in der Geschichte Europas, Gerhard Fouquet \& Gabriel Zeilinger (eds): Die Urbanisierung Europas von der Antike bis in die Moderne, Frankfurt am Main: Lang, 7-14.

Kohl, Stefan (2006): Rural England. An Invention of the Motor Industries? Robert Burden \& Stephan Kohl (eds): Landscape and Englishness, Amsterdam: Rodopi B.V.,185-206.

Lowenthal, David (2004): The Island Garden: English Landscape and British Identity, Helen Brocklehurst \& Robert Phillips (eds): History, Nationhood and the Question of Britain, Houndmills et al.: Palgrave Macmillan, 137-150.

McCluskey, Michael (2018): Change in the Village. Filming Rural Britain, Kristin Bluemel \& Michael McCluskey (eds): Rural Modernity in Britain. A Critical Intervention, Edinburgh: Edinburgh University Press, 33-49.

Modood, Tariq (2004): Britishness out of Immigration and Antiracism, Helen Brocklehurst \& Robert Phillips (eds): History, Nationhood and the Question of Britain, Houndmills et al.: Palgrave Macmillan, 85-98.

Roe, Maggie (2014) \& Ken Taylor (eds): New Cultural Landscapes, New York: Routledge.

Roe, Maggie \& Ken Taylor (2014a): New cultural landscapes. Emerging issues, context and themes, Maggie Roe \& Ken Taylor (eds): New Cultural Landscapes, New York: Routledge, 1-23.

Shaw, Samuel (2018): Weighing Down the Landscape: The Quarry as a Site of Rural Modernity, Kristin Bluemel \& Michael McCluskey (eds): Rural Modernity in Britain. A Critical Intervention, Edinburgh: Edinburgh University Press, 69-83.

Smith, Adam I.P. (2004): National Identity, Re-enactment and Conflict: A usable Past?, Helen Brocklehurst \& Robert Phillips (eds): History, Nationhood and the Question of Britain, Houndmills et al.: Palgrave Macmillan, 302-311.

Trimm, Ryan (2018): Heritage and the Legacy of the Past in Contemporary Britain, New York et al.: Routledge.

Tschiggerl, Martin, Thomas Walach \& Stefan Zahlmann (2019): Geschichtstheorie, Wiesbaden: Springer.

Stuart Wand (2004): The End of Empire and the Fate of Britishness, Helen Brocklehurst \& Robert Phillips (eds): History, Nationhood and the Question of Britain, Houndmills et al.: Palgrave Macmillan, 242-258.

Zahlmann, Stefan (2015): Tiere und Medien, Gesine Krüger, Aline Steinbrecher \& Clemens Wischermann (eds): Tiere und Geschichte. Konturen einer Geschichte der 


\section{Culture Unbound}

Journal of Current Cultural Research

Animate History, Stuttgart: Steiner, 153-170.

\section{Episodes}

In addition to the two case studies in my essay the episodes listed below are referenced. Even if not cited, my remarks are based on all episodes between the pilot and Series (= S) 19, Episode (= E) 5, which have been watched at least once. I follow the counting of the Wikipedia page (https://en.wikipedia.org/wiki/List of Midsomer_Murders episodes\#Series 7 (2003\%E2\%80\%9304). The year listed is the year that the episodes were first aired.

\section{Case studies}

Midsomer Murders, "The Killings at Badger's Drift", ITV, March 231997

Director: Jeremy Silberton; screenplay: Anthony Horowitz, based on a novel by Caroline Graham; producer: Betty Willingdale, Brian True-May; cast: John Nettles (DCI Tom Barnaby), Daniel Casey (Sgt. Gavin Troy), Jane Wymark (Joyce Barnaby), Laura Howard (Cully Barnaby), Barry Jackson (Dr. Bullard), Renee Asherson (Emily Simpson), Rosalie Crutchley (Lucy Bellringer), Jonathan Firth (Michael Lacey), Emily Mortimer (Katherine Lacey), Julian Glover (Henry Trace), Selina Cadell (Phyllis Cadell), Christopher Villiers (David Whitely), Richard Cant (Dennis Rainbird), Elizabeth Spriggs (Iris Rainbird).

Midsomer Murders, “The Dark Rider”, ITV, February 12012

Director: Alex Pillai; screenplay: Michael Aitkens; producer: Jo Wright; cast: Neil Dudgeon (DCI John Barnaby), Jason Hughes (DS Ben Jones), Fiona Dolman (Sarah Barnaby), Tamzin Malleson (Dr. Kate Wilding), Raquel Cassidy (Diana DeQuetteville), Kerry Fox (Betty DeQuetteville), James Callis (Toby/Julian DeQuetteville), William Gaunt (Ludo DeQuetteville), Eleanor Bron (Lady Isobel „Izzy“ DeQuetteville), James Clay (Simon DeQuetteville), Murray Melvin (Bentham DeQuettville), Natalie Mendoza (Sasha Fleetwood)

Paul Ritter (Harry Fleetwood), Louisa Clein (Amanda Harding).

\section{Additional episodes}

S01 E01 Written in Blood (1998)

S01 E03 Faithful unto Death (1998)

S01 E04 Death in Disguise (1998)

S02 E01 Death's Shadow (1999)

S02 E02 Strangler's Wood (1999)

S02 E03 Dead Man's Eleven (1999)

S02 E04 Blood Will Out (1999)

S03 E01 Death of a Stranger (1999) 
S03 E02 Blue Herrings (2000)

S03 E03 Judgment Day (2000)

S04 E01 Garden of Death (2000)

S07 E02 Bad Tidings (2004)

S07 E04 Sins of Commission (2004)

S07 E06 The Straw Woman (2004)

S08 E03 Orchis Fatalis (2005)

S08 E06 Hidden Depths (2005)

S08 E07 Sauce for the Goose (2005)

S09 E02 Dead Letters (2006)

S10 E06 Picture of Innocence (2007)

S12 E02 The Black Book (2009)

S12 E03 Secrets and Spies (2009)

S13 E03 Blood on the Saddle (2009)

S14 E83 Dark Secrets (2011)

S14 E07 A Sacred Trust (2011)

S16 E02 Let Us Pray (2014)

S18 E02 The Incident at Cooper Hill (2016)

S18 E06 Harvest of Souls (2016)

S19 E02 Crime and Punishment (2016)

S19 E03 Last Man Out (2017)

S19 E04 Red in Tooth and Claw (2017)

\section{Links}

All of the following links were visited for the last time on Feb 282019.

http://midsomermurders.org/midsomer.htm

https://en.wikipedia.org/wiki/List_of_Midsomer_Murders_episodes\#Series 7 $(2003 \% \mathrm{E} 2 \% 80 \% 9304)$

https://www.bbc.com/news/uk-12741847

https://www.radiotimes.com/news/2011-03-23/midsomer-murders-boss-brian-truemay-to-step-down/

https://www.theguardian.com/media/2011/mar/23/midsomer-murders-brian-truemay-english 